\title{
A New Flavanone as a Potent Antioxidant Isolated from Chromolaena odorata L. Leaves
}

\author{
Devi Anggraini Putri $(\mathbb{D})$ and Sri Fatmawati \\ Laboratory of Natural Products and Synthetic Chemistry, Department of Chemistry, Faculty of Science, \\ Institut Teknologi Sepuluh Nopember, Surabaya 60111, Indonesia \\ Correspondence should be addressed to Sri Fatmawati; fatma@chem.its.ac.id
}

Received 29 December 2018; Accepted 20 May 2019; Published 18 June 2019

Guest Editor: Irawan W. Kusuma

Copyright (C) 2019 Devi Anggraini Putri and Sri Fatmawati. This is an open access article distributed under the Creative Commons Attribution License, which permits unrestricted use, distribution, and reproduction in any medium, provided the original work is properly cited.

\begin{abstract}
Chromolaena odorata L. (Asteraceae) is one of the tropical plants which is widely used as traditional medicines for diabetes and soft tissue wounds treatment in some regions in East Indonesia. The present study was aimed at determining the bioactive compounds of $C$. odorata leaves. The methanol and ethyl acetate extracts of $C$. odorata leaves have the inhibitory activity against 2,2-diphenyl-1-picryl-hydrazyl (DPPH) and 2,2'-azinobis-(3-ethylbenzothiazoline-6-sulfonic acid) (ABTS) radicals as well as $\alpha$ glucosidase rat intestine enzyme. A new flavanone was isolated from the methanol extract and elucidated as 5,3'-dihydroxy-7,6'dimethoxyflavanone or, namely, odoratenin (1) together with two known compounds: isosakuranetin (2) and subscandenin (3). The antioxidant activity of odoratenin (1) exhibited very potent ABTS radical inhibitory activity with $\mathrm{IC}_{50}$ value of $23.74 \mu \mathrm{M}$ which is lower than that of trolox $\left(\mathrm{IC}_{50} 31.32 \mu \mathrm{M}\right)$ as a positive control. The result showed that a new flavanone, odoratenin (1), should be potential as an antioxidant source.
\end{abstract}

\section{Introduction}

Antioxidant is a bioactive substance preventing the oxidation of the harmful chemicals. That oxidation is caused by free radicals that have unpaired electrons. So, those free radicals are very reactive to damage molecules in cell [1]. During the past decade, a lot of antioxidant products are consumed by people in the world as the synthetic drugs, supplements, or traditional medicines. The traditional medicines have been taken by people in the world derived from the natural sources like medicinal plants according to World Health Organization (WHO) data. 65\% of population in India consume the medicinal plants as a primary health. The $40 \%$ of prescription drugs in China are also based on the component of medicinal plants. In addition, $70 \%$ of Canadians have also used the medicinal plants as both a health supplement and an alternative therapeutic product [2]. In Indonesia, the medicinal plants are recognized as jamu. Approximately $85 \%$ of jamu's ingredients are the extract of medicinal plants. Hence, a number of modern or synthetic medicines are made from the isolation of natural sources based on the traditional plant medicines [3]. One of the natural sources that has been used as a medicinal plant is Chromolaena odorata $\mathrm{L}$.

C. odorata (Asteraceae) is one of the species of Chromolaena genus that has been identified by King and Robinson in 1970. C. odorata is recognized as siam weed. It is one of the invasive species with a rapid growth forming the thick bushes as high as about two meters. Besides, it spreads rapidly on the open areas such as grasslands, roadsides, forests, nature reserves, and wildlife sanctuaries [4]. Actually, C. odorata is used as a medicinal plant by people lived in the tropic and subtropic areas. For example, in Vietnam, this plant is used as a treatment of leech bites, soft tissue injuries, burns, and skin infections [5]. Furthermore, a leaf water extract is widely used as a diarrhea, malaria, and diabetes drug [6]. Additionally, this leaf is also used as the treatment of wounds because the leaf's contents are protein, carbohydrate, and fiber source [7].

The previous studies have reported that most of the Chromolaena genus contains the flavonoids group. Based on a review information by Oliveira et al. (2017), they reported that about 40 flavonoids have been identified from this genus. One of species from this genus, C. hirsuta, has been reported 
to contain quercetin and kaempferol derivatives which belong to flavonoids group [8]. Some researchers also reported that C. odorata contains the flavonoid compounds [9-15]. In addition, the qualitative phytochemical properties of $C$. odorata leaves extract also showed the presence of secondary metabolite compounds such as coumarins, flavonoids, tannins, and sterols [16]. Currently, this preceding research aims to isolate and identify other secondary metabolite compounds of $C$. odorata leaves. Furthermore, the antioxidant activity of the compounds will be assayed.

Recently, some researchers reported that $C$. odorata showed bioactivity as an antibacterial [17], antifungal [18, 19], anti-inflammatory [20, 21], anticancer [11, 13, 22], antiplasmodial [9], antidiabetic [23, 24], and antioxidant [6, 25-28]. Rao et al. (2010) reported in vitro antioxidant activity of chloroform extract of $C$. odorata leves. The antioxidant activity was presented by using 2,2'-azinobis(3-ethylbenzothiazoline-6-sulfonic acid) (ABTS) assay. The result showed a good inhibition with value of $\mathrm{IC}_{50}(1.32$ $\mathrm{mg} / \mathrm{mL})$ compared to standard ascorbic acid $(1.00 \mathrm{mg} / \mathrm{mL})$ [28]. Furthermore, the antioxidant activity was also reported by ABTS assay from ethanol extract of $C$. odorata. The result showed a good amount of activity inhibition about 29.92$63.34 \%$ [26]. In addition, the significant activity was also obtained with polysaccharide fraction of C. odorata (91.91 $\pm 0.9 \%$ ) by the same assay method [6]. However, its $\mathrm{IC}_{50}$ value, both research of Parameswari \& Suriyavathana (2013) and Boudjeko et al. (2015), is not reported yet. Based on these studies, $C$. odorata has been recognized potentially as an antioxidant source. In the present study, the further research aims to identify the compounds of methanol extract from $C$. odorata leaves as an antioxidant.

\section{Materials and Methods}

2.1. Chemicals. The chemicals used were 2,2-diphenyl-1picryl-hydrazyl (DPPH) (TCI, 1898-66-4), 2,2'-azinobis(3-ethylbenzothiazoline-6-sulfonic acid) (ABTS) (Wako), pottasium peroxydisulphate $\left(\mathrm{K}_{2} \mathrm{~S}_{2} \mathrm{O}_{8}\right)$, Folin-Ciocalteu's phenol reagent (FCR) (Merck), anhydrous sodium carbonate $\left(\mathrm{Na}_{2} \mathrm{CO}_{3}\right)$, rat intestinal acetone powder (Sigma, 1639), glucose kit liquor (HUMAN), acarbose, gallic acid, 6hydroxy-2,5,7,8-tetramethylchromen-2-carboxylate acid (trolox) (Wako), and dimethylsulfoxide (DMSO) (Merck). Solvents ( $n$-hexane, dichroloromethane, ethyl acetate, methanol, and ethanol) were purchased from Anhui Fulltime specialized solvents \& reagents Co., Ltd. (Anhui, China).

2.2. General Experimental Procedures. The purity of the compounds was determined by column chromatography (CC) using silica gel 60 G (Merck), silica gel 60 (0,063-0,200 $\mathrm{mm}$ ), and Sephadex LH-20. For thin layer chromatography (TLC) analysis, silica gel $60 \mathrm{~F}_{245}$ aluminium sheets (Merck) were used. Spots were visualized under UV light and sprayed with $\mathrm{CeSO}_{4}$ in $\mathrm{H}_{2} \mathrm{SO}_{4}$ solution followed by heating. FisherJohns was used as melting point apparatus. The IR data were obtained on a Shimadzu FT-IR-8400S spectrometer using the $\mathrm{KBr}$ method. The $1 \mathrm{D}$ - and 2D-NMR, including ${ }^{1} \mathrm{H}$ and ${ }^{13} \mathrm{C}$ NMR, HMBC (Heteronuclear Multiple Bond Correlation), and HMQC (Heteronuclear Multiple Quantum Coherence) spectra, were measured on a DELTA2_NMR spectrometer (JEOL, $400 \mathrm{MHz}$ ) with tetramethylsilane as a standard in $\mathrm{CDCl}_{3}$. The molecular formula was confirmed by using Xevo G2-XS QTof LC-MS-MS with ESI for type of ionization. The absorbance data were measured on UV-Vis Genesys Thermo Scientific $10 \mathrm{~S}$ spectrophotometer.

2.3. Plant Material. The leaves of $C$. odorata were collected on August 2017 at Ambon, Maluku Province, Indonesia. The plant was identified with a voucher specimen (48) by Pamela Papila, a botanist at the Fundamental Biology Laboratory, Pattimura University, Indonesia.

2.4. Extraction. The dried leaves of C. odorata (30 g) were extracted with various solvents for the bioactivity preparation assay. The leaves were dried in room temperature. They were extracted by using $n$-hexane, dichloromethane, ethyl acetate, methanol, and water in $200 \mathrm{~mL}$ of solvent for each extract at room temperature for 24 hours. The solvent was removed from the extracts by rotary evaporator to obtain the five crude extracts.

2.5. Fractionation. The dried leaves of C. odorata $(2.76 \mathrm{~kg})$ were extracted during $3 \times 24$ hours at room temperature in $10 \mathrm{~L} \mathrm{MeOH}$ for each time. The solvent was removed from the extract by rotary evaporator to yield $832 \mathrm{~g}$ of extract $(30.15 \%$ yield). $90 \mathrm{~g}$ of methanol extract was then fractionated by CC vacuum on silica gel $60 \mathrm{G}(480 \mathrm{~g})$ with a gradient elution of $\mathrm{CH}_{2} \mathrm{Cl}_{2}(100 \%)$, EtOAc (100\%), and $\mathrm{MeOH}(100 \%)$, each $5.4 \mathrm{~L}$ to obtain three fractions (A-C). Fraction A $(25.6 \mathrm{~g})$ was further subjected to CC vacuum (Si gel $60 \mathrm{G}, 180 \mathrm{~g}$ ) with a step gradient elution of $n$-hexane:EtOAc (99:1, 97:3, 93:7, 90:10, 75:25, 50:50, 25:75, and 0:100, $v / v$, each $900 \mathrm{~mL}$ ) and $\mathrm{MeOH}$ to obtain five subfractions (A1-A5). Subfraction A3 (6.4 g) was subjected to CC vacuum (Si gel 60 G, 92 g) with a step gradient elution of $n$-hexane:EtOAc (93:7, 92:8, 91:9, 90:10, 88:12, 86:14, 82:18; 80:20, 50:50, 20:80, and $0: 100, v / v$, each $500 \mathrm{~mL}$ ) and $\mathrm{MeOH}$, respectively, to obtain eight subfractions (A3A-A3H). Furthermore, subfraction A3E (1.7 g) was subjected to Sephadex LH-20 CC eluted with $\mathrm{CH}_{2} \mathrm{Cl}_{2}: \mathrm{MeOH}(1: 1, v / v)$ to yield five subfractions (A3E1A3E5). Subfraction A3E4 (0.6 g) was subjected to Sephadex LH-20 CC eluted with $\mathrm{CH}_{2} \mathrm{Cl}_{2}: \mathrm{MeOH}(1: 1, v / v)$ to obtain four subfractions (A3E4A-A3E4D). A compound (2) (29.8 mg) was obtained by purification of subfraction A3E4C $(100 \mathrm{mg})$ with recrystallization technique. Furthermore, subfraction A3E4B (400 mg) was separated by using silica gel $60 \mathrm{CC}$ $(50 \mathrm{~g})$ eluted with $\mathrm{CH}_{2} \mathrm{Cl}_{2}(100 \%)$ to afford compound (1) (54.1 mg) and six subfractions (A3E4B1-A3E4B6). The compound of (1) was obtained by purification of subfraction A3E4B1 (100 mg). And compound (3) (5 mg) was obtained by purification of subfraction A3E4B2B2B3 (80 mg).

\subsection{Antioxidant Activity}

2.6.1. Determination of Total Phenolic Contents. The total phenolic content of various $C$. odorata extracts (the $n$-hexane, dichloromethane, ethyl acetate, methanol, and water extracts) 
was determined according to the procedure of Qassabi et al. (2018) with slight modifications [29]. The total phenolic content was determined by applying gallic acid calibration curve and expressed in mg of gallic acid equivalents (GAE)/g crude extracts. Each extract $(1 \mathrm{mg} / \mathrm{mL})$ was dissolved in methanol to prepare a sample solution. The absorbance of sample solution was determined by using UV-Vis Genesys Thermo Scientific $10 S$ spectrophotometer with those following steps. First, the mixture solution between $66 \mu \mathrm{L}$ of sample solution and 500 $\mu \mathrm{L}$ of $10 \%$ FCR solution was mixed and incubated in a dark place for 5 minutes. Then, $500 \mu \mathrm{L}$ of $6 \% \mathrm{Na}_{2} \mathrm{CO}_{3}$ was added into the solution, mixed well, and left for 90 minutes in the dark place. Finally, the absorbance of sample solution was measured by UV-Vis spectrophotometer at $\lambda 750 \mathrm{~nm}$.

2.6.2. DPPH Radical Scavenging Assay. DPPH assay was performed based on the method published previously [30]. First, DPPH solution $\left(6 \times 10^{-5} \mathrm{M}\right)$ was separated by dissolving $2.37 \mathrm{mg}$ of DPPH in $100 \mathrm{~mL}$ of methanol to obtain a working solution. Then, $1 \mathrm{~mL}$ the working solution was mixed with $33 \mu \mathrm{L}$ of samples ( $n$-hexane, dichloromethane, ethyl acetate, methanol, and water extracts) at maximum dissolved concentration in methanol and mixed well. Finally, the mixed sample solution was incubated for 20 minutes at room temperature. Then, the absorbance $\left(\mathrm{A}_{\mathrm{s}}\right)$ of the reaction mixture was measured by UV-Vis spectrophotometer at 517 $\mathrm{nm}$. The mixed solution between methanol and the working solution was used as blank to give the blank absorbance $\left(A_{b}\right)$. Gallic acid was used as a standard. The inhibitory activity was calculated by (1). The $\mathrm{IC}_{50}$ value is expressed as a quantity of an extract inhibitory concentration against a half of DPPH radicals.

$$
\operatorname{Inhibition}(\%)=\left[\frac{\left(A_{b}-A_{s}\right)}{A_{b}}\right] \times 100
$$

2.6.3. ABTS Radical Cation Scavenging Assay. Free radical scavenging by ABTS radical was based on the method described previously by us [30]. First, ABTS solution (7 mM) was prepared by dissolving $19.2 \mathrm{mg}$ of ABTS in $5 \mathrm{~mL}$ of water and, then, $140 \mathrm{mM} \mathrm{K}_{2} \mathrm{~S}_{2} \mathrm{O}_{8}$ in $88 \mu \mathrm{L}$ of water. Those two solutions were mixed and incubated for 12-16 hours to obtain ABTS radical cation solution which is a dark blue solution. It was added with $\pm 274 \mathrm{~mL}$ of ethanol to give an absorbance of $0.7 \pm 0.02$ units at $734 \mathrm{~nm}$ for making a working solution. 1 $\mathrm{mL}$ of working solution was mixed with $10 \mu \mathrm{L}$ of samples $(n-$ hexane, dichloromethane, ethyl acetate, methanol, and water extracts) at maximum dissolved concentration in DMSO and mixed well. Finally, the mixed sample solution was incubated for four minutes at room temperature; then, the absorbance $\left(\mathrm{A}_{\mathrm{s}}\right)$ of the reaction mixture was measured by UV-Vis spectrophotometers at $734 \mathrm{~nm}$. The mixed solution between DMSO and the working solution was used as blank to give the blank absorbance $\left(A_{b}\right)$. Trolox was used as a standard. The inhibitory activity was calculated by (1). The $\mathrm{IC}_{50}$ value was expressed as a quantity of an extract inhibitory concentration against a half of ABTS radicals.
2.7. $\alpha$-Glucosidase Inhibitory Activity Assay. The $\alpha$ glucosidase inhibitory assay was performed based on the procedure from Ayinampudi et al., (2012) with some modifications [31]. First, rat intestinal acetone powder (1 g) was suspended in $30 \mathrm{~mL}$ of normal saline. This suspended solution was sonicated for five minutes at $4^{\circ} \mathrm{C}$. After centrifugation $\left(12,000 \mathrm{rpm}, 30\right.$ minutes, $\left.4^{\circ} \mathrm{C}\right)$, the resulting supernatant was used for the assay. Briefly, a mixture of $10 \mu \mathrm{L}$ samples, $30 \mu \mathrm{L}$ of $0.1 \mathrm{M}$ phosphate buffer ( $\mathrm{pH}$ 6.9), $20 \mu \mathrm{L}$ of $10 \mathrm{mM}$ maltose, $80 \mu \mathrm{L}$ glucose kit, and $20 \mu \mathrm{L}$ of enzyme supernatant were incubated in 96-well plates at $37^{\circ} \mathrm{C}$ for 10 minutes. Acarbose was used as a standard. The absorbance was recorded at $490 \mathrm{~nm}$ by microplate reader (Biotek ELx800UV). The inhibitory activity was determined from the formula as follows:

$$
\text { Inhibition }(\%)=\left[\frac{\left(A_{\text {blank }}-A_{\text {sample }}\right)}{A_{\text {blank }}}\right] \times 100
$$

where $A_{\text {blank }}=A_{\text {enzyme reaction }}-A_{\text {blank of enzyme reaction }}$ and $\mathrm{A}_{\text {sample }}=\mathrm{A}_{\text {sample reaction }}-\mathrm{A}_{\text {blank of sample reaction }}$.

\section{Results}

3.1. Extraction. The five crude extracts from C. odorata leaves have been obtained. The methanol extract has the highest yield of all extracts. From $30 \mathrm{~g}$ dried leaves in $200 \mathrm{~mL}$ of each solvent, the yields of the five extracts were obtained such as $4.33 \%$ yield of $n$-hexane, $6.77 \%$ yield of dichloromethane, $7.33 \%$ yield of ethyl acetate, $10.00 \%$ yield of methanol, and $7.33 \%$ yield of water extract.

3.2. Total Phenolic Content. The total phenolic content of different extracts of $C$. odorata leaves was determined by using FCR according to the procedure of Qassabi et al. (2018) with slight modifications. The tested extracts are $n$-hexane, dichloromethane, ethyl acetate, methanol, and water extracts at concentration $61.91 \mu \mathrm{g} / \mathrm{mL}$. The evaluated result of total phenolic content of each extract is showed in Table 1. Gallic acid was used as a standard for calibration curve to determine the amount of total phenolic content. Based on study, the total phenolic content of different extracts varied from 14.65 to $104.08 \mu \mathrm{gGAE} / \mathrm{mg}$ of extract. The ethyl acetate extract is the highest amount of total phenolic content of all the extracts with value of $104.08 \mu \mathrm{gGAE} / \mathrm{mg}$ of ethyl acetate extract.

3.3. DPPH Radical Scavenging Activity. DPPH radical scavenging activity of the five extracts and gallic acid as a standard are presented in Figure 1 and summarized in Table 1. Based on these $\mathrm{IC}_{50}$ values, the dichloromethane, ethyl acetate, and methanol extracts are potential antioxidant against $\mathrm{DPPH}$ radicals with $\mathrm{IC}_{50}$ value of $90.83,57.26$, and $188.61 \mu \mathrm{g} / \mathrm{mL}$, respectively. According to this result, the ethyl acetate extract is the highest inhibitory activity against $\mathrm{DPPH}$ radicals among other extracts. The minimum of $\mathrm{IC}_{50}$ value indicates a good free radical scavenging activity.

3.4. ABTS Radical Cation Scavenging Activity. ABTS radical cation scavenging activity of the five extracts, compounds 
TABLE 1: Antioxidant and $\alpha$-glucosidase activities of the extracts and compounds from C. odorata.

\begin{tabular}{|c|c|c|c|c|}
\hline Samples & Total phenolic contents ( $\mu \mathrm{g}$ GAE/mg of sample) $\pm \mathrm{SD}^{1}$ & $\begin{array}{c}\mathrm{DPPH} \\
\mathrm{IC}_{50}(\mu \mathrm{g} / \mathrm{mL}) \pm \\
\mathrm{SD}^{1}\end{array}$ & $\begin{array}{c}\text { ABTS } \\
\mathrm{IC}_{50}(\mu \mathrm{g} / \mathrm{mL}) \pm \\
\mathrm{SD}^{1}\end{array}$ & $\begin{array}{c}\alpha \text {-Glucosidase } \\
\text { inhibition } \\
\mathrm{IC}_{50}(\mu \mathrm{g} / \mathrm{mL}) \pm \\
\mathrm{SD}^{1}\end{array}$ \\
\hline \multicolumn{5}{|c|}{ Samples (Extracts of C. odorata) } \\
\hline$n$-Hexane & $14.65 \pm 0.98$ & $>319.46$ & $>99.01$ & $>1250$ \\
\hline Dichloromethane & $74.84 \pm 2.11$ & $90.83 \pm 0.31$ & $13.97 \pm 0.22$ & $>1250$ \\
\hline Ethyl acetate & $104.08 \pm 3.87$ & $57.26 \pm 1.07$ & $24.43 \pm 0.09$ & $779.54 \pm 6.16$ \\
\hline Methanol & $57.11 \pm 4.85$ & $188.61 \pm 3.31$ & $46.80 \pm 2.91$ & $1329.31 \pm 2.68$ \\
\hline Water & $27.49 \pm 1.41$ & $>319.46$ & $21.37 \pm 0.89$ & $>1250$ \\
\hline \multicolumn{5}{|c|}{ Samples (the compounds isolated from C. odorata) } \\
\hline Odoratenin (1) & $\mathrm{NS}^{2}$ & $\mathrm{NS}^{2}$ & $7.51 \pm 1.57$ & $>62.5$ \\
\hline Isosakuranetin (2) & $\mathrm{NS}^{2}$ & $\mathrm{NS}^{2}$ & $>9.9$ & $>312.5$ \\
\hline Subscandenin (3) & $\mathrm{NS}^{2}$ & $\mathrm{NS}^{2}$ & $\mathrm{NS}^{2}$ & $\mathrm{NS}^{2}$ \\
\hline \multicolumn{5}{|l|}{ Standard } \\
\hline Gallic acid & as a standard curve & $1.11 \pm 0.42$ & $\mathrm{NS}^{2}$ & $\mathrm{NS}^{2}$ \\
\hline Trolox & $\mathrm{NS}^{2}$ & $\mathrm{NS}^{2}$ & $7.84 \pm 0.45$ & $\mathrm{NS}^{2}$ \\
\hline Acarbose & $\mathrm{NS}^{2}$ & $\mathrm{NS}^{2}$ & $\mathrm{NS}^{2}$ & $7.67 \pm 1.86$ \\
\hline
\end{tabular}

${ }^{1}$ values represent the means \pm standard deviations for triplicate experiments.

${ }^{2}$ not studied.

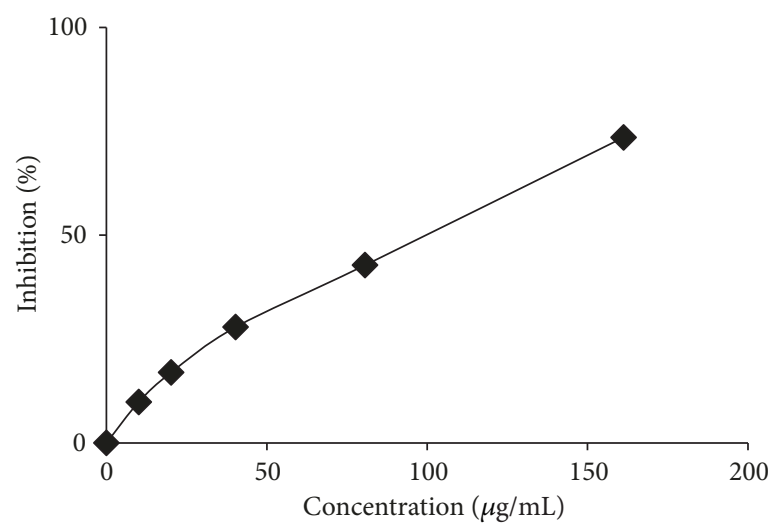

(a)

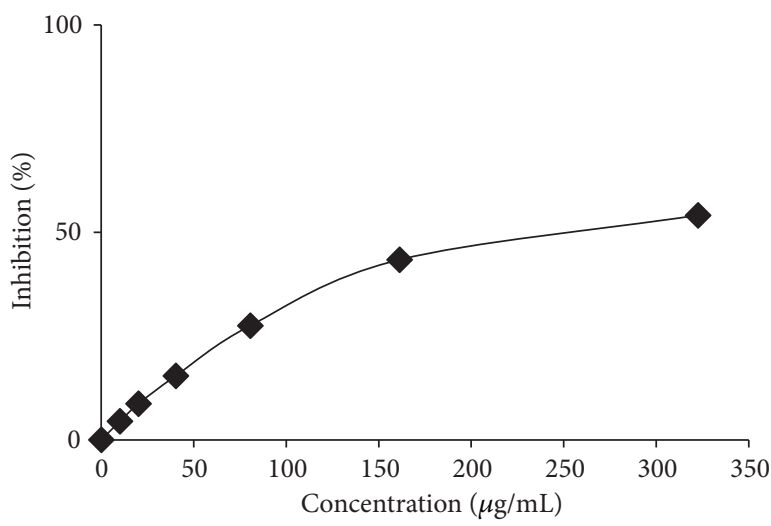

(c)

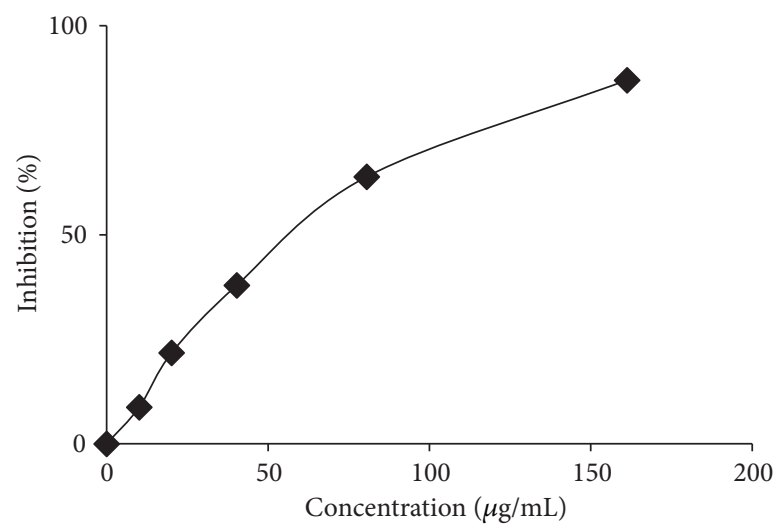

(b)

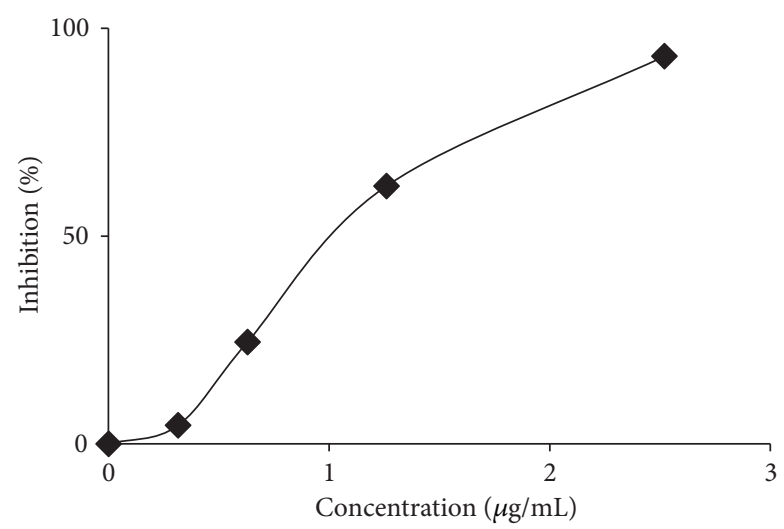

(d)

FIGURE 1: DPPH radical scavenging activity of C. odorata (a) dichloromethane, (b) ethyl acetate, (c) methanol extracts, and (d) gallic acid as a standard. 


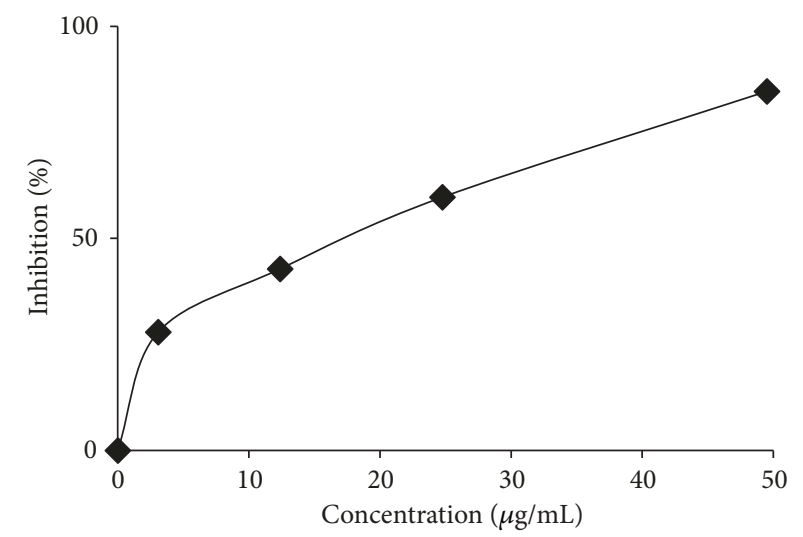

(a)

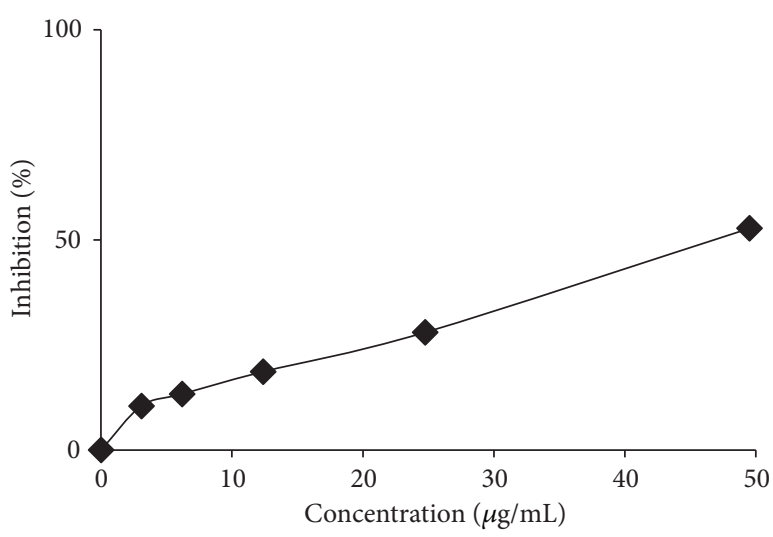

(c)

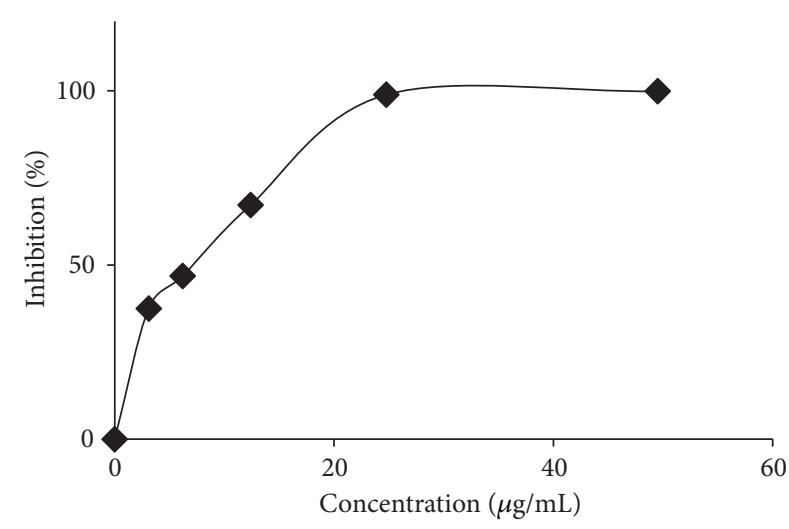

(e)

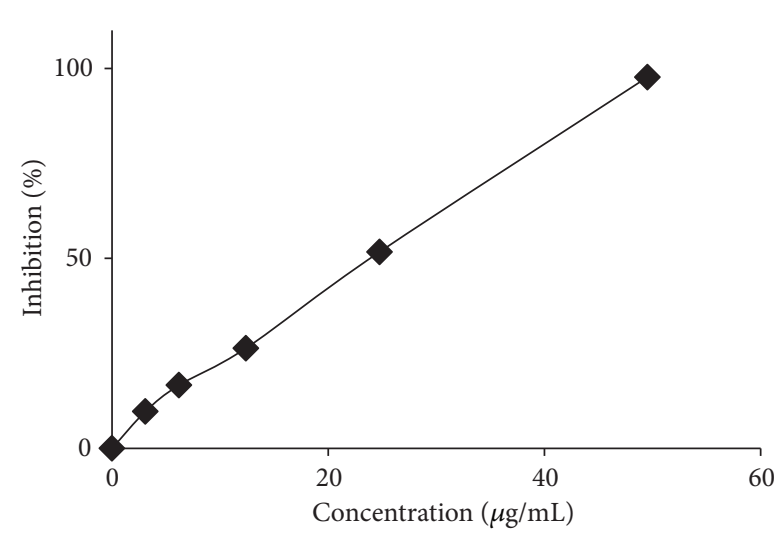

(b)

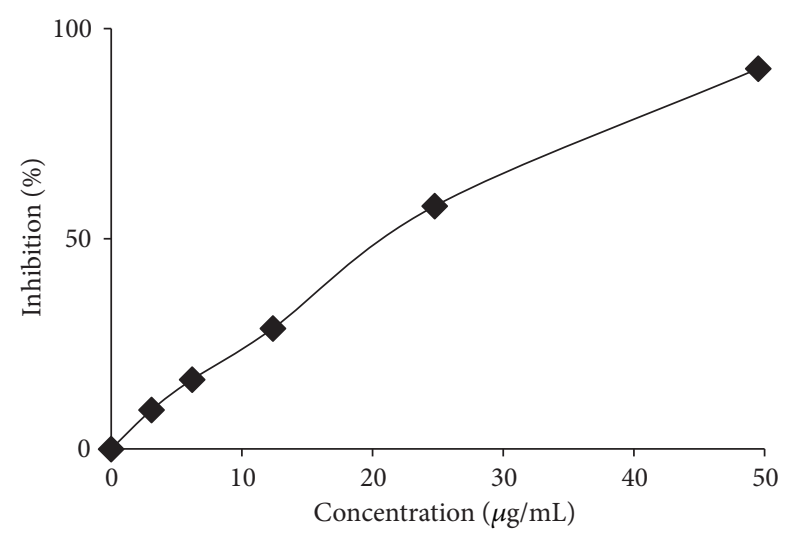

(d)

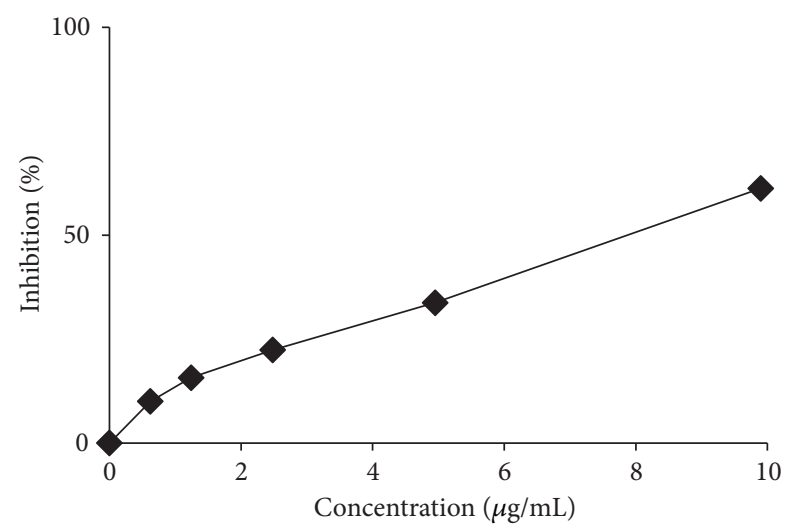

(f)

FIGURE 2: ABTS scavenging activity of C. odorata (a) dichloromethane, (b) ethyl acetate, (c) methanol, (d) water extracts, (e) trolox as a standard, and (f) odoratenin (1).

isolated from C. odorata, and trolox as a standard are presented in Figure 2 and summarized in Table 1. According to these $\mathrm{IC}_{50}$ values, both the extracts and compounds are potential antioxidant against ABTS radical cations. The $\mathrm{IC}_{50}$ values of dichloromethane, ethyl acetate, methanol, and water extracts are $13.97,24.43,46.79$, and $21.37 \mu \mathrm{g} / \mathrm{mL}$, respectively. Interestingly, odoratenin (1) is higher free radical scavenging activity than that of the various extracts with $\mathrm{IC}_{50}$ value of 7.51 $\mu \mathrm{g} / \mathrm{mL}(23.74 \mu \mathrm{M})$ also compared with trolox as a standard with $\mathrm{IC}_{50}$ value of $31.32 \mu \mathrm{M}$.
3.5. $\alpha$-Glucosidase Inhibitory Activity. Rat intestinal acetone powder was used in this assay system. The five extracts, compounds isolated from $C$. odorata, and acarbose as a standard are showed in Figure 3 and summarized in Table 1. In this assay system, the ethyl acetate extract was found to be slightly more active than that of the methanol extract. In contrast, the $n$-hexane, dichloromethane, water, and the compounds (1-2) had a weak effect on the enzyme activity. The ethyl acetate extract presented the inhibitory activity with an $\mathrm{IC}_{50}$ value of $779.54 \mu \mathrm{g} / \mathrm{mL}$. Acarbose, which is known as 


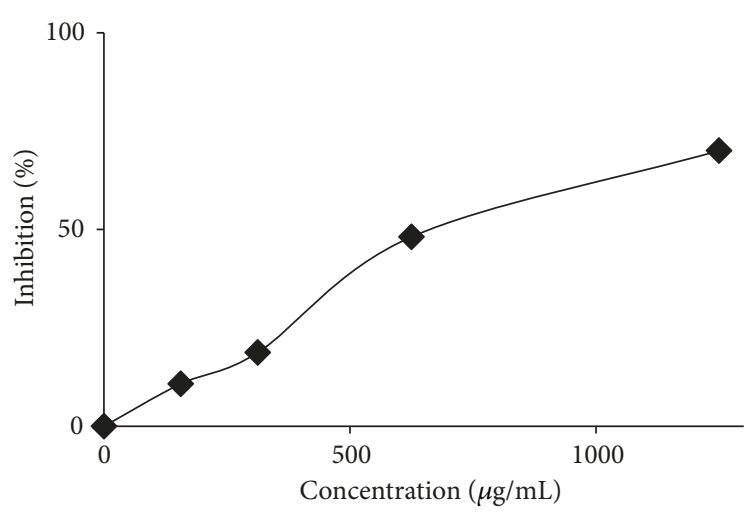

(a)

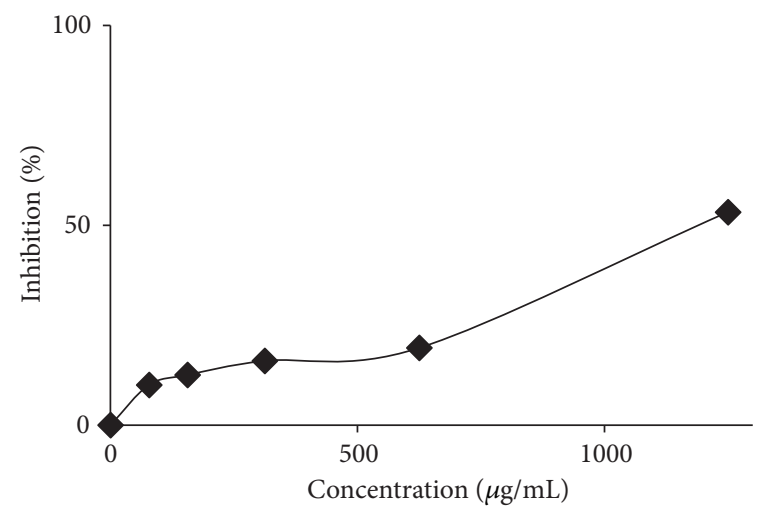

(b)

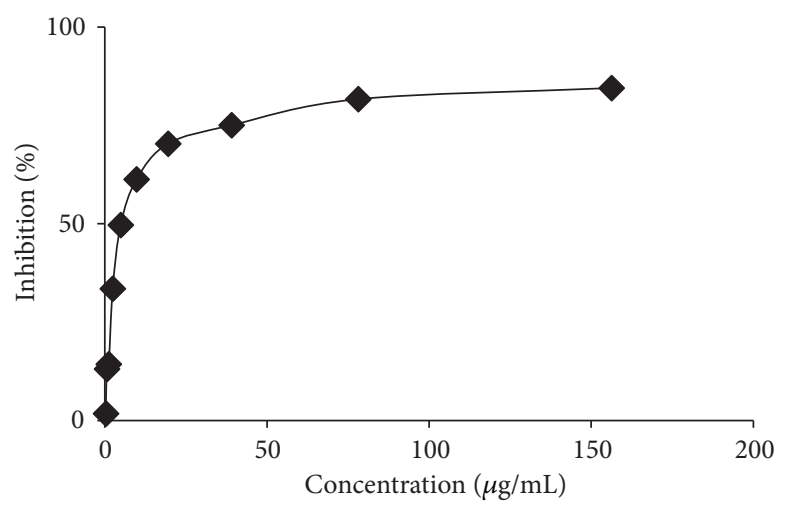

(c)

FIgURE 3: $\alpha$-Glucosidase inhibitory activity of $C$. odorata (a) ethyl acetate, (b) methanol extracts, and (c) acarbose as a standard.

a potent $\alpha$-glucosidase inhibitor, was used as a standard and showed an $\mathrm{IC}_{50}$ of $7.67 \mu \mathrm{g} / \mathrm{mL}$ in our assay system.

3.6. Odoratenin (1). White crystal; mp: $144-145^{\circ} \mathrm{C} ;[\alpha]_{25}^{D}$ $16.0^{\circ}\left(\mathrm{CHCl}_{3} ; c=0.001\right)$; IR $v_{\max }(\mathrm{KBr}): 3518,2943,1629$, $1593,1519,1442,1300,1278,1201,810 \mathrm{~cm}^{-1}$; for ${ }^{1} \mathrm{H}(400 \mathrm{MHz}$, $\left.\mathrm{CDCl}_{3}\right),{ }^{13} \mathrm{C}$ NMR $\left(400 \mathrm{MHz}, \mathrm{CDCl}_{3}\right), \mathrm{HMQC}$, and $\mathrm{HMBC}$ spectroscopic data are presented in Figure 4 and summarized in Table 2; and HR-ESI-MS $m / z 339.0831[\mathrm{M}+\mathrm{Na}]^{+}$(cald. for $\left.\mathrm{C}_{17} \mathrm{H}_{16} \mathrm{O}_{6} \mathrm{Na}, 339.3090\right)$.

3.7. Isosakuranetin (2). White needles; $\mathrm{mp}: 173-174^{\circ} \mathrm{C} ; \mathrm{IR} \nu_{\max }$ (KBr): 3504, 2955, 1639, 1599, 1518, 1492, 1302, 1253, 1163, 833 $\mathrm{cm}^{-1}$; for ${ }^{1} \mathrm{H}\left(400 \mathrm{MHz}, \mathrm{CDCl}_{3}\right)$ and ${ }^{13} \mathrm{C}$ NMR $(400 \mathrm{MHz}$, $\mathrm{CDCl}_{3}$ ) spectroscopic data are presented in Table 2.

3.8. Subscandenin (3). Yellow needles; $\mathrm{mp}: 174-175^{\circ} \mathrm{C}$; for ${ }^{1} \mathrm{H}\left(400 \mathrm{MHz}, \mathrm{CDCl}_{3}\right),{ }^{13} \mathrm{C}$ NMR $\left(400 \mathrm{MHz}, \mathrm{CDCl}_{3}\right)$ and HMBC spectroscopic data are presented in Table 2.

\section{Discussion}

4.1. Antioxidant Activities of C. odorata. C. odorata is a species of the genus Chromolaena which is one of the largest genera of the family Eupatorieae (Asteraceae) [8]. In Indonesia, C. odorata, known as sungga-sungga, was collected from
Ambon, Maluku, East Indonesia. This plant is a popular folk medicine widely used as alternative herbal treatment for diabetes and soft tissue wounds in East Indonesia. Besides, in Vietnam, this plant is used as a treatment of leech bites, soft tissue injuries, burns, and skin infections [5]. Furthermore, a leaf water extract is widely used as a diarrhea, malaria, and diabetes drug [6]. In the past 40 years, this plant has been reported in phytochemical studies in the United States $[14,15]$. Recently, C. odorata was described for its beneficial attributes in some Asia-Africa countries, especially the pharmacological effects of this plant. The specific reported attributes of $C$. odorata include being antibacterial [17], antifungal $[18,19]$, anti-inflammatory $[20,21]$, anticancer $[11,13,22]$, antiplasmodial [9], antidiabetic [23, 24], and antioxidant $[6,25-28]$. However, the antioxidant activity of the isolated compound from C. odorata has never been reported.

This present study demonstrated the antioxidant activity of the isolated compound from C. odorata for the first time. Related to this study, the antioxidant effect from this plant has been done by two radical scavenging assays supported with the total phenolic content data. As we know, there are a lot of free radical types caused of reactive oxygen species (ROS) [32]. They are the dangerous free radicals against the human body. These free radicals come from either the body itself or the external factors. The free radicals are by products 
TABLE 2: 1D- and 2D NMR spectroscopic data of compounds (1-3) in $\mathrm{CDCl}_{3}$.

\begin{tabular}{|c|c|c|c|c|c|c|c|c|}
\hline \multirow{2}{*}{ Position } & \multicolumn{2}{|c|}{ Isosakuranetin (2) } & \multicolumn{3}{|c|}{ Odoratenin (1) } & \multicolumn{3}{|c|}{ Subscandenin (3) } \\
\hline & $\delta_{\mathrm{H}}(J$ in $\mathrm{Hz})$ & $\delta_{c}$ & $\delta_{\mathrm{H}}(J$ in $\mathrm{Hz})$ & $\delta_{\mathrm{c}}$ & HMBC & $\delta_{\mathrm{H}}(J$ in $\mathrm{Hz})$ & $\delta_{\mathrm{c}}$ & HMBC \\
\hline 2 & $\begin{array}{c}5.36(\mathrm{dd} ; J=13.2,3.2 \\
\mathrm{Hz}, 1 \mathrm{H})\end{array}$ & 79.10 & $\begin{array}{c}5.32(\mathrm{dd} ; J=12.8,3.2 \\
\mathrm{Hz}, 1 \mathrm{H})\end{array}$ & 79.06 & - & $\begin{array}{c}5.34(\mathrm{dd} ; J=13.2,3.2 \\
\mathrm{Hz}, 1 \mathrm{H})\end{array}$ & 79.13 & - \\
\hline $3 a$ & $\begin{array}{c}2.78(\mathrm{dd} ; J=17.8,3.2 \\
\mathrm{Hz}, 1 \mathrm{H})\end{array}$ & 43.20 & $\begin{array}{c}2.78(\mathrm{dd} ; J=17.0,3.2 \\
\mathrm{Hz}, 1 \mathrm{H})\end{array}$ & 43.30 & $\mathrm{C}-4$ & $\begin{array}{c}2.77(\mathrm{dd} ; J=17.2,3.2 \\
\mathrm{Hz}, 1 \mathrm{H})\end{array}$ & 43.29 & $\mathrm{C}-4$ \\
\hline $3 b$ & $\begin{array}{c}3.09(\mathrm{dd} ; J=17.0,13.2 \\
\mathrm{Hz}, 1 \mathrm{H})\end{array}$ & & $\begin{array}{c}3.07(\mathrm{dd} ; J=17.2,12.8 \\
\mathrm{Hz}, 1 \mathrm{H})\end{array}$ & & $\mathrm{C}-2,4$ & $\begin{array}{c}3.07(\mathrm{dd} ; J=17.2,12.8 \\
\mathrm{Hz}, 1 \mathrm{H})\end{array}$ & & $\mathrm{C}-2,4$ \\
\hline 4 & - & 196.18 & - & 196.07 & - & & 196.96 & - \\
\hline 5 & $12.04(\mathrm{~s} ; 1 \mathrm{H})$ & 164.43 & $12.01(\mathrm{~s} ; 1 \mathrm{H})$ & 162.93 & $\begin{array}{c}\mathrm{C}-6,7,8 \\
10\end{array}$ & $12.19(\mathrm{~s} ; 1 \mathrm{H})$ & 158.78 & - \\
\hline 6 & $\begin{array}{c}5.97(\mathrm{~d} ; J=2.4 \mathrm{~Hz} \\
1 \mathrm{H})\end{array}$ & 96.76 & $\begin{array}{c}6.06(\mathrm{~d} ; J=2.8 \mathrm{~Hz} \\
1 \mathrm{H})\end{array}$ & 95.19 & $\mathrm{C}-4,7,9,10$ & $6.10(\mathrm{~s} ; 1 \mathrm{H})$ & 94.66 & $\begin{array}{c}\mathrm{C}-5,8,9, \\
10\end{array}$ \\
\hline 7 & $5.76($ br s; $1 \mathrm{H})$ & 164.59 & - & 164.19 & & $6.46($ br s; $1 \mathrm{H})$ & 154.43 & - \\
\hline 7-OMe & - & - & $3.82(\mathrm{~s} ; 3 \mathrm{H})$ & 55.79 & C-9 & - & - & - \\
\hline 8 & $\begin{array}{c}5.99(\mathrm{~d} ; J=2.4 \mathrm{~Hz} \\
1 \mathrm{H})\end{array}$ & 95.54 & $\begin{array}{c}6.04(\mathrm{~d} ; J=2.4 \mathrm{~Hz} \\
1 \mathrm{H})\end{array}$ & 94.33 & C- $6,9,10$ & - & 128.38 & - \\
\hline 8-OMe & - & - & - & - & - & $3.94(\mathrm{~s} ; 3 \mathrm{H})$ & 61.09 & C- 4,8 \\
\hline 9 & - & 163.36 & - & 168.05 & - & - & 157.50 & - \\
\hline 10 & - & 103.20 & - & 103.20 & - & - & 103.19 & - \\
\hline $1^{\prime}$ & - & 130.36 & - & 147.06 & - & - & 130.36 & - \\
\hline $2^{\prime}$ & $\begin{array}{c}7.37(\mathrm{~d} ; J=8.8 \mathrm{~Hz} \\
1 \mathrm{H})\end{array}$ & 114.33 & $\begin{array}{c}7.04(\mathrm{~d} ; J=2,0 \mathrm{~Hz} \\
1 \mathrm{H})\end{array}$ & 112.73 & $\mathrm{C}-2,1,4$ & $6.95(\mathrm{~d} ; J=10 \mathrm{~Hz}, 1 \mathrm{H})$ & 127.81 & $\begin{array}{l}\text { C-1', 3', 4', } \\
5^{\prime}\end{array}$ \\
\hline $3^{\prime}$ & $\begin{array}{c}6.95(\mathrm{~d} ; J=8.4 \mathrm{~Hz} \\
1 \mathrm{H})\end{array}$ & 127.85 & $5.69(\mathrm{~s} ; 1 \mathrm{H})$ & 145.99 & - & $7.37(\mathrm{~d} ; J=9,2 \mathrm{~Hz}, 1 \mathrm{H})$ & 114.30 & $\begin{array}{l}\text { C-1', 2', } 4^{\prime}, \\
6^{\prime}\end{array}$ \\
\hline $4^{\prime}$ & - & 160.14 & $6.91(\mathrm{~d}, J=1.6 \mathrm{~Hz}, 1 \mathrm{H})$ & 118.26 & C-1' & - & 160.13 & - \\
\hline 4'-OMe & $3.83(\mathrm{~s} ; 3 \mathrm{H})$ & 55.48 & - & - & - & $3.82(\mathrm{~s} ; 3 \mathrm{H})$ & 55.46 & C-4' \\
\hline 5 & $\begin{array}{c}6.95(\mathrm{~d} ; J=8.4 \mathrm{~Hz} \\
1 \mathrm{H})\end{array}$ & 127.85 & $\begin{array}{c}6.88(\mathrm{~d} ; J=8.4 \mathrm{~Hz} \\
1 \mathrm{H})\end{array}$ & 110.72 & $\begin{array}{c}\text { C-2, 2', 3', } \\
6\end{array}$ & $7.37(\mathrm{~d} ; J=9.2 \mathrm{~Hz}, 1 \mathrm{H})$ & 114.30 & $\begin{array}{c}\text { C-1', 2', 4', } \\
6{ }^{\prime}\end{array}$ \\
\hline $6^{\prime}$ & $\begin{array}{c}7.37(\mathrm{~d} ; J=8.8 \mathrm{~Hz} \\
1 \mathrm{H})\end{array}$ & 114.33 & - & 131.59 & - & $6.95(\mathrm{~d} ; J=10 \mathrm{~Hz}, 1 \mathrm{H})$ & 127.81 & $\begin{array}{l}\text { C-1', 3', 4', } \\
5^{\prime}\end{array}$ \\
\hline 6'-OMe & - & - & $3.92(\mathrm{~s} ; 3 \mathrm{H})$ & 56.14 & C-1' & - & - & - \\
\hline
\end{tabular}

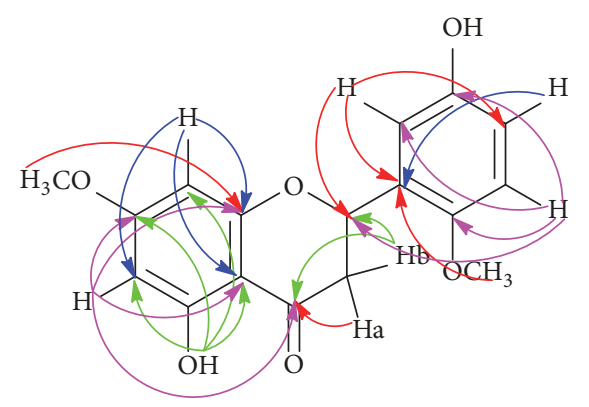

(a)

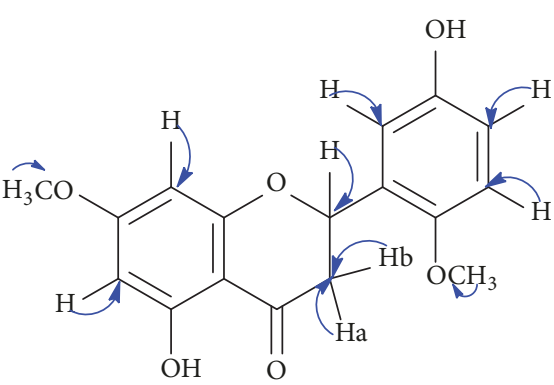

(b)

FIgURE 4: (a) HMBC and (b) HMQC correlations of odoratenin (1).

of energy production by mitochondria which are energyproducing cells as adenosine triphosphate (ATP), while the external factors come from the pollutions, ultraviolet radiation, diet, or lifestyle. Furthermore, the free radicals have an unpaired electron so this condition makes them to be reactive with other molecules around them [33]. Then, the molecules in cells are attacked by free radicals. Normally, the body's antioxidant defence system can block the free radicals before they become harmful to the body. Unfortunately, because of the old age or a lot of toxin that accumulate inside, the defence system works slowly and then the free radicals start to cause cell damage. The cell damage caused by free radicals is called 
oxidative stress. On the long term, the danger of free radicals inside is related to aging and chronic diseases such as cancer, diabetes, and neurodegenerative and cardiovascular diseases.

In the body, free radicals are superoxide anion (SOA) from $2.5 \%$ oxygen $\left(\mathrm{O}_{2}\right)$. The using of $\mathrm{O}_{2}$ in the body as a distributor of energy products changes because of free radicals of SOA. Because of that, the body is protected from those free radicals by its antioxidant defence system with these following steps [34]. First, SOA is neutralized by the antioxidant enzyme superoxide dismutase (SOD) changed as hydrogen peroxide $\left(\mathrm{H}_{2} \mathrm{O}_{2}\right) \cdot \mathrm{H}_{2} \mathrm{O}_{2}$ is a weak free radical which is used as an immune compound to inhibit the pathogen bacteria or to treat the broken cell tissue. However, the large amounts of $\mathrm{H}_{2} \mathrm{O}_{2}$ will be toxic for the body. So, there is the second step from the body's defence system that helped with glutathione peroxidase (GPO) enzyme. Two GPOs covert $\mathrm{H}_{2} \mathrm{O}_{2}$ into two water molecules $\left(\mathrm{H}_{2} \mathrm{O}\right)$. Certainly, $\mathrm{H}_{2} \mathrm{O}$ is safer than that of $\mathrm{H}_{2} \mathrm{O}_{2}$. Those two steps are very important to protect the cell body. Unfortunately, there is not enough amount of SOD and GPO in the body. So, the amount of free radicals of SOA and $\mathrm{H}_{2} \mathrm{O}_{2}$ will increase in the cell. The SOA and $\mathrm{H}_{2} \mathrm{O}_{2}$ might not be worse. But in excess, they will react with each other into more dangerous free radicals, namely, hydroxyl radicals $(\bullet \mathrm{OH})$. Hence, an antioxidant is needed as a resistance support from the outside of the body's defence system [35].

Studies are in our laboratory to identify the antioxidant compound present in C. odorata. The determination of the antioxidant effect was assayed by using DPPH and ABTS radicals. As we described previously, there are a lot of free radical types caused by ROS including DPPH and ABTS radicals. DPPH radicals are expressed as the free radical with high reactivity at room temperature. The high reactivity is caused by delocalization of electrons around the molecules. The mechanism of radical scavenging is hydrogen donors. When the DPPH radical is reacted with a substance that donates a hydrogen atom, DPPH radical is reduced into a nonradical DPPH. In the assay, this reaction is characterized by decolorization of the solution. It changes its colour solution from purple to yellow. At room temperature, ABTS radical is more stable and has higher reactivity than that of $\mathrm{DPPH}$. The ABTS radicals are expressed as cation radical with high reactivity ability [36]. The radical cation is formed from the oxidation reaction between ABTS and buffer solution especially using $\mathrm{K}_{2} \mathrm{~S}_{2} \mathrm{O}_{8}$. Furthermore, the mechanism of radical scavenging as well as DPPH's mechanism is hydrogen donors [35]. Thus, the antioxidant activity for both of the two assays is evaluated by using UV-Vis Genesys Thermo Scientific spectrophotometer.

According to this study, there is a linear relationship between the antioxidant activity and total phenolic content. This evidence means that the higher the total phenolic content, the higher the antioxidant activity. Among the five tested extracts, the ethyl acetate extract exhibited the highest antioxidant activity against either DPPH or ABTS because of the high amount of total phenolic content. Not only the ethyl acetate extract, but also the dichloromethane, methanol, and water extracts, showed fine antioxidant activity as well as the ethanol and chloroform extracts reported previously
$[27,28]$. However, there was only weak activity in the $n$ hexane extract. These results suggest the presence of phenolic compounds could be major contributor to antioxidant activity. The phenolic compounds including xanthone [37] or stilbene [38] have been reported as a potent antioxidant activity. Based on this study, the phenolic compounds of $C$. odorata could be extracted by the polar and semipolar solvents very well. When the methanol extract was fractionated and elucidated, the major secondary metabolite came from flavanone compounds which is one of the phenolic groups. The finding of a new flavanone, odoratenin (1), indicates the presence of two hydroxyls and two methoxyl group. They might be donated and the hydrogen atom also supported the electron conjugation system from the phenolic ring for stabilizing the free radicals. Interestingly, the new compound odoratenin (1) has higher antioxidant activity than that of trolox as a standard. The present study and these results reveal odoratenin (1) isolated from $C$. odorata as a potent antioxidant source.

4.2. $\alpha$-Glucosidase Inhibitory Activity of C. odorata. Diabetes mellitus is a metabolic disorder caused by a lack of insulin [39]. Insulin helps the blood glucose level to be a normal circumstance and not turn into hyperglycemia or hypoglycaemia. According to the type of an abnormal insulin, diabetes mellitus is divided into two types [40]. The first type is known as insulin dependent diabetes mellitus (IDDM) caused by a genetic factor such as the destruction of pancreatic $\beta$-cells which produce insulin and type 2 is non-insulin dependent diabetes (NIDDM) caused by a wrong lifestyle especially on diet. This study focuses on the effective treatment for type 2. As we know, carbohydrates are the major components of our daily foods, for instance, polysaccharides or disaccharides. After carbohydrates intake, the amount of polysaccharides is transformed into monosaccharides as known as the simple sugars, and then they are transferred through the bloodstream system for energy [41]. However, before they are transferred, they are absorbed on the intestine. In the small intestinal tissue, there is a catalyse of the cleavage of polysaccharides to glucose, namely, $\alpha$-glucosidase. It makes the total of glucose too large. Certainly, the increasing of glucose level as known as hyperglycemia in the blood is not good enough for health $[42,43]$. Related to hyperglycemia, $\alpha$ glucosidase inhibitor is recommended as antidiabetic [44].

In this assay system, the rat intestinal acetone powder has been used as enzyme to determine the antidiabetic inhibitory activity of $C$. odorata extracts. The tested extracts might inhibit or compete with maltose as a substrate. Based on our work, there is a linear correlation between $\alpha$-glucosidase inhibition and antioxidant activity. The ethyl acetate and methanol extracts performed a fine inhibitory activity. This result as well as the antioxidant activity screening previously reported that these two extracts have a good radical scavenging activity also against both DPPH and ABTS radicals. Furthermore, the isolated compound from $C$. odorata reported a significantly higher $\alpha$-glucosidase inhibitory activity than that of deoxynojirimycin and acarbose as the standards in previous research [24]. From this study, it should be noted that the $\alpha$-glucosidase inhibitory effect of the ethyl acetate 
<smiles>COc1cc(O)c2c(c1)OC(c1cc(O)ccc1OC)CC2=O</smiles>

(1)<smiles>COc1ccc(C2CC(=O)c3c(O)cc(O)cc3O2)cc1</smiles>

(2)<smiles>COc1ccc(C2CC(=O)c3c(O)cc(O)c(OC)c3O2)cc1</smiles>

(3)

FIGURE 5: The structures of odoratenin (1), isosakuranetin (2), and subscandenin (3) isolated from the leaves of C. odorata methanol extract.

extract from $C$. odorata was almost the same as that of the methanol extract.

4.3. The Flavanones Isolated from C. odorata. Antioxidant evaluation of the methanol extract from the leaves of $C$. odorata led to finding of a bioactive compound as well as a new flavanone, odoratenin (1), along with two known compounds: isosakuranetin (2) and subscandenin (3). The structure of a new compound (1) was elucidated by using 1D- and 2D-NMR spectroscopy analysis and the structures of the known compounds (2) and (3) were determined and compared with the published NMR spectroscopic data previously.

Odoratenin (1) was obtained as a white crystal. Its molecular formula was determined as $5,3^{\prime}$-dihydroxy-7,6'dimethoxyflavanone $\left(\mathrm{C}_{17} \mathrm{H}_{16} \mathrm{O}_{6}\right)$ by HR-ESI-MS measurement through the hydrogen ion at $m / z 317.1013[\mathrm{M}+\mathrm{H}]^{+}$ and the sodium ion at $\mathrm{m} / z$ 339.0831 $[\mathrm{M}+\mathrm{Na}]^{+}$(calcd. for $\mathrm{C}_{17} \mathrm{H}_{16} \mathrm{O}_{6} \mathrm{Na}, 339.3090$ ). The IR spectrum showed characteristic absorption bands for hydroxyl chelated carbonyl stretching bonds at 3518 and $1629 \mathrm{~cm}^{-1}$, indicating the presence of a flavonoid group. The NMR assignments were made by applying $1 \mathrm{D}$ - and $2 \mathrm{D}-\mathrm{NMR}$ experiments $\left({ }^{1} \mathrm{H} \mathrm{NMR}\right.$, ${ }^{13} \mathrm{C} \mathrm{NMR}, \mathrm{HMBC}$, and HMQC; $\left.\mathrm{CDCl}_{3}, 400 \mathrm{MHz}\right)$. The ${ }^{1} \mathrm{H}$ NMR spectrum (Table 2) showed signal for a hydrogenbonded hydroxyl proton at $\delta_{\mathrm{H}} 12.01(\mathrm{~s}, 1 \mathrm{H}, 5-\mathrm{OH})$; two aromatic protons at $\delta_{\mathrm{H}} 6.06(\mathrm{~d}, J=2.8 \mathrm{~Hz}, 1 \mathrm{H}, \mathrm{H}-6)$ and 6.04 (d, $J=2.4 \mathrm{~Hz}, 1 \mathrm{H}, \mathrm{H}-8$ ); three pyrone vicinal-geminal protons at $\delta_{\mathrm{H}} 5,32(\mathrm{dd}, J=12.8 ; 3.2 \mathrm{~Hz}, 1 \mathrm{H}, \mathrm{H}-2), 3.07$ (dd, J=17.2; $12.8 \mathrm{~Hz}, 1 \mathrm{H}, \mathrm{H}-3 \mathrm{~b}$ ), and 2.77 (dd, $J=17.0 ; 3.2 \mathrm{~Hz}, 1 \mathrm{H}, \mathrm{H}-3 \mathrm{a})$ indicating the presence of a flavanone which are similar to the ${ }^{1} \mathrm{H}$ NMR spectrum of known compound, isosakuranetin (2); three aromatic protons with abx-system at $\delta_{\mathrm{H}} 7.04(\mathrm{~d}$,
$\left.J=2.0 \mathrm{~Hz}, 1 \mathrm{H}, \mathrm{H}-2^{\prime}\right), 6.91\left(\mathrm{dd}, J=1.6 \mathrm{~Hz}, 1 \mathrm{H}, \mathrm{H}-4^{\prime}\right)$, and 6.88 $\left(\mathrm{d}, J=8.4 \mathrm{~Hz}, 1 \mathrm{H}, \mathrm{H}-5^{\prime}\right)$; and six methoxy protons at $\delta_{\mathrm{H}}$ $3.92(\mathrm{~s}, 3 \mathrm{H}, 6$ '-OMe) and $3.82(\mathrm{~s}, 3 \mathrm{H}, 7-\mathrm{OMe})$. Based on the ${ }^{13} \mathrm{C}$ NMR spectrum, there are 17 carbon signals of this compound (1) including a carbonyl group of C-4 $\left(\delta_{\mathrm{C}} 196.07\right)$, one chiral carbon of C-2 $\left(\delta_{\mathrm{C}} 79.06\right)$ with $[\alpha]_{25}^{D}-16.0^{\circ}$ as the absolute configuration, two carboxyl groups (-C-OH) of C-5 and $\mathrm{C}-3^{\prime}\left(\delta_{\mathrm{C}} 162.93\right.$ and 145.99$)$, and two methoxy carbons $\left(-\mathrm{OCH}_{3}\right)$ of $7-\mathrm{OCH}_{3}$ and $6{ }^{\prime}-\mathrm{OCH}_{3}\left(\delta_{\mathrm{C}} 55.79\right.$ and 56.14). However, there is the only one methoxy carbon of 4 ' $-\mathrm{OCH}_{3}$ $\left(\delta_{\mathrm{C}}\right.$ 55.48) in isosakuranetin (2). The long-range hydrogen to carbon correlations were assigned and confirmed by twodimensional NMR (HMBC and HMQC) as Figures 4(a) and 4(b). The HMBC correlations showed that a hydrogenbonded hydroxyl proton at $\delta_{\mathrm{H}} 12.01(5-\mathrm{OH})$ correlated with C-6 $\left(\delta_{\mathrm{C}} 95.19\right), \mathrm{C}-7\left(\delta_{\mathrm{C}} 164.19\right), \mathrm{C}-8\left(\delta_{\mathrm{C}} 94.33\right)$, and C-10 $\left(\delta_{\mathrm{C}}\right.$ 103.20) showing that the hydroxyl group was attached to $\mathrm{C}$ 5. Two vicinal-geminal protons at $\delta_{\mathrm{H}} 3.07(3-\mathrm{Hb})$ and 2.77 (3-Ha) were attached to carbon carbonyl (C-4, $\delta_{\mathrm{C}}$ 196.07). Besides, the $3-\mathrm{Hb}$ proton correlated with $\mathrm{C}-2\left(\delta_{\mathrm{C}} 79.06\right)$ showing that the vicinal-geminal protons were attached to $\mathrm{C}-3$. Furthermore, five aromatic protons were placed at C6, C-8, C-2', C-4', and C-5'. They have hydrogen-to-carbon correlations between H-6/C-4, C-7, C-9, C-10; H-8/C-6, C7, C-9, C-10; H-2'/C-2, C-1', C-4'; H-4'/C-1'; H-5'/C-2, C-2', C-3', C-6' which were also confirmed by HMQC spectrum as Figure 4(b). Accordingly, both hydroxyl and methoxy substituents were assigned as 3'-hydroxy [9, 13] and 8methoxy [14] at C-3' and C-8. Interestingly, although more than 79 flavonoid compounds have been isolated from the genus Chromolaena [8], the methoxy substituent at C-6' has not been reported yet before. Accordingly, the compound of (1) is a new flavanone named odoratenin (1) as in Figure 5 (1). 
Isosakuranetin (2) is a white needles solid powder with a melting point of $173-174^{\circ} \mathrm{C}$. The elucidation process of isosakuranetin (2) was determined as these following steps. First, the FT-IR data showed the strong intensity of peaks as follows, $\nu_{\text {maks }}(\mathrm{KBr}): 3504,2955,1639,1599,1518,1492$, $1302,1253,1163$, and $833 \mathrm{~cm}^{-1}$. The peaks of $3504 \mathrm{~cm}^{-1}$ with medium intensity and $1639 \mathrm{~cm}^{-1}$ with strong intensity revealed the presence of a hydroxyl $(-\mathrm{OH})$ group chelated with carbonyl group $(-\mathrm{C}=\mathrm{O})$. In addition, the peaks of 1518 , 1492 , and $833 \mathrm{~cm}^{-1}$ with medium to weak intensities indicated the presence of a conjugated aromatic group. Furthermore, this information was confirmed by data ${ }^{1} \mathrm{H}$ and ${ }^{13} \mathrm{C}-\mathrm{NMR}$ $\left(\mathrm{CDCl}_{3}, 400 \mathrm{MHz}\right)$ presented in Table 2. Based on the presented data, there are a number of detected chemical shifts as 14 protons and 16 carbons. The 14 proton signals including the singlet signal of $\delta_{\mathrm{H}} 12.04 \mathrm{ppm}$ with integration in the downfield area indicated the presence of one proton as 5$\mathrm{OH}$. This proton is deshielded because it bonds with $\mathrm{O}$ atom which has more electrons directly to be a hydroxyl group and also as a typical signal at the same time. The typical signal means a hydroxyl proton chelated with a carbonyl group. So, the proton has a far chemical shift. Next, a strong singlet signal of $\delta_{\mathrm{H}} 3.83 \mathrm{ppm}$ with three integration processes in the upfield area showed three protons as $4^{\prime}-\mathrm{OCH}_{3}$. They are shielded because they do not bond with $\mathrm{O}$ atom directly. So, these three protons have near chemical shifts and also they are suspected strongly to be protons from the methoxy group. Furthermore, three signals with doublet multiplicity at $\delta_{\mathrm{H}}$ $5.36(\mathrm{H}-2), 2.78(\mathrm{H}-3 \mathrm{a})$, and $3.09 \mathrm{ppm}(\mathrm{H}-3 \mathrm{~b})$ coupling with the vicinal-geminal proton system indicated the presence of a pyran group [45]. This proton system indicated strongly that compound (2) is one of the flavanone groups which is similar to a previous known compound reported by Suksamrarn et al. (2004) [13]. In addition, the doublet signals of $\delta_{\mathrm{H}} 7.37$ (H-2'/6') and $6.95 \mathrm{ppm}\left(\mathrm{H}-3^{\prime} / 5^{\prime}\right)$ coupling with each other with double intensity showed four proton signals indicating the protons of an aromatic group. Based on our results, compound (2) has a flavanone skeleton with an ABC ring system substituted with the methoxy and hydroxyl groups as Figure 5 (2). Furthermore, two signal doublets of $\delta_{\mathrm{H}} 5.97$ and 5.99 ppm also coupling with each other are strongly suspected as two signals of aromatic potons as H-6 and H8 on ring $\mathrm{A}$. The determination of the structure of compound (2) is confirmed with ${ }^{13} \mathrm{C}-\mathrm{NMR}$ data. Based on our ${ }^{13} \mathrm{C}$ NMR data, there are 16 carbons including a carbon carbonyl group which is strongly expected as a position of C- $4\left(\delta_{\mathrm{C}}\right.$ $196.18 \mathrm{ppm})$, one chiral carbon assumed as a position of C-2 $\left(\delta_{\mathrm{C}} 79.10 \mathrm{ppm}\right)$, one carbon methoxy at position of C-4' $\left(\delta_{\mathrm{C}} 55.48 \mathrm{ppm}\right)$, and the aromatic carbon expected as the position of $\mathrm{C}-2^{\prime} / 6^{\prime}\left(\delta_{\mathrm{C}} 114.33 \mathrm{ppm}\right)$ and $\mathrm{C}-3^{\prime} / 5^{\prime}\left(\delta_{\mathrm{C}}\right.$ $127.85 \mathrm{ppm})$ with double intensity, respectively. And the other aromatic carbons including $\delta_{\mathrm{C}}$ 95.54, 96.76, 103.20, $130.36,160.14,163.36,164.53$, and $164.59 \mathrm{ppm}$. Based on this elucidation study, compound (2) is an isosakuranetin (2) as in Figure 5 (2) which was also isolated by Suksamrarn et al. (2004).

Subscandenin (3) is yellow needles solid powder with a melting point of $174-175^{\circ} \mathrm{C}$. Compound (3) is strongly expected as subscandenin which is one of the derivatives from flavanone compounds with a skeleton similar to compounds (1-2). The structure is confirmed by the interpretation of ${ }^{1} \mathrm{H}$, ${ }^{13} \mathrm{C}-\mathrm{NMR}$, and $\mathrm{HMBC}$ data $\left(\mathrm{CDCl}_{3}, 400 \mathrm{MHz}\right)$ presented in Table 2. The results of the NMR characterization showed characters that are similar to the NMR characterization of compounds (1-2). Based on the presented data, there are a number of detected chemical shifts as 16 protons and 17 carbons. This total of protons and carbons is equal to the total of compound (1). The ${ }^{1} \mathrm{H}$ NMR spectrum (Table 2) showed signal for a hydrogen-bonded hydroxyl proton at $\delta_{\mathrm{H}} 12.19(\mathrm{~s}$, $1 \mathrm{H}, 5-\mathrm{OH})$; two aromatic protons at $\delta_{\mathrm{H}} 6.10(\mathrm{~s}, 1 \mathrm{H}, \mathrm{H}-6)$ and 6.46 (br s, $1 \mathrm{H}, \mathrm{H}-7$ ); three pyrone vicinal-geminal protons at $\delta_{\mathrm{H}} 5.34(\mathrm{dd}, J=13.2 ; 3.2 \mathrm{~Hz}, 1 \mathrm{H}, \mathrm{H}-2), 3.07$ (dd, $J=17.2$; $12.8 \mathrm{~Hz}, 1 \mathrm{H}, \mathrm{H}-3 \mathrm{~b}$ ), and 2.77 (dd, $J=17.2 ; 3.2 \mathrm{~Hz}, 1 \mathrm{H}, \mathrm{H}-3 \mathrm{a})$ indicating the presence of a flavanone which are similar to the ${ }^{1} \mathrm{H}$ NMR spectrum of the known compounds, odoratenin (1) and isosakuranetin (2); four aromatic protons at $\delta_{\mathrm{H}} 6.95$ (d, J=10 Hz, 2H, H-2'/6') and 7.37 (d, J=9.2 Hz, 2H, H3'/5'); and six methoxy protons at $\delta_{\mathrm{H}} 3.94(\mathrm{~s}, 3 \mathrm{H}, 8-\mathrm{OMe})$ and 3.82 (s, 3H, 4'-OMe). Based on the ${ }^{13} \mathrm{C}$ NMR spectrum, there are 17 carbon signals of compound (3) including a carbonyl group $\left(\delta_{\mathrm{C}} 196.96\right)$, one chiral carbon $\left(\delta_{\mathrm{C}} 79.13\right)$, two carboxyl groups $\left(\delta_{\mathrm{C}} 158.78\right.$ and 114.30), and two methoxy carbons $\left(\delta_{\mathrm{C}} 61.09\right.$ and 55.46). The long-range hydrogen to carbon correlations were assigned and confirmed by HMBC spectrum presented in Table 2. The HMBC correlation data confirmed the existence of 18 correlations between protons and carbons. These results showed the structure of compound (3) is different from either compound (1) or compound (2). The signal correlation showed a relationship between proton methoxy of $4^{\prime}-\mathrm{OCH}_{3}\left(\delta_{\mathrm{H}} 3.82 \mathrm{ppm}\right)$ with carbon of $\mathrm{C}-4$ $\left(\delta_{\mathrm{c}} 160.13 \mathrm{ppm}\right)$ and other proton methoxy of $8-\mathrm{OCH}_{3}\left(\delta_{\mathrm{H}}\right.$ $3.94 \mathrm{ppm})$ with two carbons of C-4 $\left(\delta_{\mathrm{c}} 196.96 \mathrm{ppm}\right)$ and C-8 $\left(\delta_{\mathrm{c}} 128.38 \mathrm{ppm}\right)$. This signal correlation revealed the position of the methoxy of $4^{\prime}-\mathrm{OCH}_{3}\left(\delta_{\mathrm{H}} 3.82 \mathrm{ppm}\right)$ on ring $\mathrm{B}$ and other methoxy group of $8-\mathrm{OCH}_{3}\left(\delta_{\mathrm{H}} 3.94 \mathrm{ppm}\right)$ on ring A. Furthermore, there are four correlations between protons and aromatic carbon on ring $\mathrm{B}$, namely, proton of $\mathrm{H}$ $3^{\prime} / 5^{\prime}\left(\delta_{\mathrm{H}} 7.37 \mathrm{ppm}\right)$ correlating with four carbons of C-1 $\left(\delta_{\mathrm{c}}\right.$ $130.36 \mathrm{ppm}), \mathrm{C}-2^{\prime} / 6^{\prime}\left(\delta_{\mathrm{c}} 127.81 \mathrm{ppm}\right.$ with double integrations), and $\mathrm{C}-4^{\prime}\left(\delta_{\mathrm{c}} 160.13 \mathrm{ppm}\right)$. The same thing happened to proton of $\mathrm{H}-2$ ' $/ 6 /\left(\delta_{\mathrm{H}} 6.95 \mathrm{ppm}\right)$ which also correlated with four carbons of C-1' $\left(\delta_{c} 130.36 \mathrm{ppm}\right), \mathrm{C}-3^{\prime} / 5^{\prime}\left(\delta_{\mathrm{c}} 114.30\right.$ with double integrations), and $\mathrm{C}-4^{\prime}\left(\delta_{\mathrm{c}} 160.13 \mathrm{ppm}\right)$. These correlation evidences assumed strongly that the O-methoxy binds directly to carbon of C-4'. In addition, there are four correlations between a proton and the aromatic carbons on ring $\mathrm{A}$, namely, proton of $\mathrm{H}-6\left(\delta_{\mathrm{H}} 6.10 \mathrm{ppm}\right)$ correlating with four carbons of H-5 $\left(\delta_{c} 158.78 \mathrm{ppm}\right), \mathrm{H}-8\left(\delta_{\mathrm{c}} 128.38\right.$ ppm), H-9 ( $\left.\delta_{c} 157.50 \mathrm{ppm}\right)$, and H-10 ( $\left.\delta_{\mathrm{c}} 103.19 \mathrm{ppm}\right)$. These correlation evidences assumed strongly that the O-methoxy binds directly to carbon of C-8. Based on our elucidation study, the compound of (3) is a subscandenin (3) as in Figure 5(3) which was also isolated by Amaro-Luis \& DelgadoMendez (1993). However, they reported isolated subscandenin (3) from a different species, namely, C. subscandens [14]. 


\section{Conclusion}

C. odorata, collected from East Indonesia, contributes to drug discovery and healthcare. This is the first report on the antioxidant activity of a new flavanone isolated from the $C$. odorata leaves methanol extract. Among the tested five extracts, the ethyl acetate extract exhibited the highest inhibitory effect against ABTS radical and $\alpha$-glucosidase rat intestinal enzyme. Further investigations will focus on the identification of the other active flavanone compounds responsible for the antioxidant as well as $\alpha$-glucosidase inhibitory activity of $C$. odorata leaves ethyl acetate extract.

\section{Data Availability}

The data used to support the findings of this study are available from the corresponding author upon request.

\section{Conflicts of Interest}

All authors declare that there are no conflicts of interest regarding the publication of this article.

\section{Acknowledgments}

This work was supported by a grant from Directorate General of Higher Education, Ministry of Research, Technology \& Higher Education, Indonesia. This work was also supported by the financial support for Putri, D. A. from Indonesia Endowment Fund for Education Scholarship (LPDP-RI), Ministry of Finance, Indonesia.

\section{References}

[1] W. Brand-Williams, M. E. Cuvelier, and C. Berset, "Use of a free radical method to evaluate antioxidant activity," LWT - Food Science and Technology, vol. 28, no. 1, pp. 25-30, 1995.

[2] WHO, "Traditional medicine," Fifty-sixty world health assembly, 2003.

[3] O. Tebboub, R. Cotugno, F. Oke-Altuntas et al., "Antioxidant potential of herbal preparations and components from Galactites elegans (All.) Nyman ex Saldano," Evidence-Based Complementary and Alternative Medicine, vol. 2018, Article ID 9294358, 7 pages, 2018.

[4] CABI, "Invasive Species Compendium," 2017, http://www.cabi .org/isc/datasheet/23248.

[5] T.-T. Phan, L. Wang, P. See, R. J. Grayer, S.-Y. Chan, and S. T. Lee, "Phenolic compounds of Chromolaena odorata protect cultured skin cells from oxidative damage: implication for contaneous wound healing," Biological \& Pharmaceutical Bulletin, vol. 24, no. 12, pp. 1373-1379, 2001.

[6] T. Boudjeko, R. Megnekou, A. L. Woguia et al., "Antioxidant and immunomodulatory properties of polysaccharides from Allanblackia floribunda Oliv stem bark and Chromolaena odorata (L.) King and H.E. Robins leaves," BioMed Central, vol. 8, no. 1, article no 759, 2015.

[7] A. G. Omokhua, L. J. McGaw, J. F. Finnie, and J. Van Staden, "Chromolaena odorata (L.) R.M. King and H. Rob. (Asteraceae) in sub-Saharan Africa: A synthesis and review of its medicinal potential," Journal of Ethnopharmacology, vol. 183, pp. 112-122, 2016.

[8] J. A. M. de Oliveira, D. I. Bernardi, R. B. Balbinot et al., "Chemotaxonomic value of flavonoids in Chromolaena congesta (Asteraceae)," Biochemical Systematics and Ecology, vol. 70, pp. 7-13, 2017.

[9] I. C. Ezenyi, O. A. Salawu, R. Kulkarni, and M. Emeje, "Antiplasmodial activity-aided isolation and identification of quercetin4'-methyl ether in Chromolaena odorata leaf fraction with high activity against chloroquine-resistant Plasmodium falciparum," Parasitology Research, vol. 113, no. 12, pp. 4415-4422, 2014.

[10] M.-L. Zhang, D. Irwin, X.-N. Li et al., "PPAR $\gamma$ agonist from chromolaena odorata," Journal of Natural Products, vol. 75, no. 12, pp. 2076-2081, 2012.

[11] T. M. Hung, T. D. Cuong, N. H. Dang et al., "Flavonoid glycosides from Chromolaena odorata leaves and their in vitro cytotoxic activity," Chemical \& Pharmaceutical Bulletin, vol. 59, no. 1, pp. 129-131, 2011.

[12] N. Pisutthanan, B. Liawruangrath, S. Liawruangrath, and J. B. Bremner, "A new flavonoid from Chromolaena odorata," Natural Product Research (Formerly Natural Product Letters), vol. 20, no. 13, pp. 1192-1198, 2006.

[13] A. Suksamrarn, A. Chotipong, T. Suavansri et al., "Antimycobacterial activity and cytotoxicity of flavonoids from the flowers of Chromolaena odorata," Archives of Pharmacal Research, vol. 27, no. 5, pp. 507-511, 2004.

[14] J. M. Amaro-Luis and P. Delgado-Méndez, "Flavonoids from the leaves of chromolaena subscandens," Journal of Natural Products, vol. 56, no. 4, pp. 610-612, 1993.

[15] R. N. Barua, R. P. Sharma, G. Thyagarajan, and W. Hertz, "Flavonoids of Chromolaena odorata," Phytochemistry, vol. 17, no. 10, pp. 1807-1808, 1978.

[16] E. Wollenweber, M. Dörr, and R. Muniappan, "Exudate flavonoids in a tropical weed, Chromolaena odorata (L.) R. M. King et H. Robinson," Biochemical Systematics and Ecology, vol. 23, no. 7-8, pp. 873-874, 1995.

[17] M. Atindehou, L. Lagnika, B. Guérold et al., "Isolation and identification of two antibacterial agents from $<\mathrm{i}>$ Chromolaena odorata $</ \mathrm{i}>\mathrm{L}$. active against four diarrheal strains," Advances in Microbiology, vol. 03, no. 01, pp. 115-121, 2013.

[18] K. K. Naidoo, R. M. Coopoosamy, and G. Naidoo, "Screening of Chromolaeana odorata (L.) king and robinson for antibacterial and antifungal properties," Journal of Medicinal Plant Research, vol. 5, no. 19, pp. 4859-4862, 2011.

[19] A. N. Ngane, R. E. Etame, F. Ndifor, L. Biyiti, P. H. A. Zollo, and P. Bouchet, "Antifungal activity of Chromolaena odorata (L.) King \& Robinson (Asteraceae) of Cameroon," Chemotherapy, vol. 52, no. 2, pp. 103-106, 2006.

[20] H. Pandith, X. Zhang, S. Thongpraditchote, Y. Wongkrajang, W. Gritsanapan, and S. J. Baek, "Effect of Siam weed extract and its bioactive component scutellarein tetramethyl ether on anti-inflammatory activity through NF- $\kappa$ B pathway," Journal of Ethnopharmacology, vol. 147, no. 2, pp. 434-441, 2013.

[21] T. T. H. Hanh, D. T. T. Hang, C. Van Minh, and N. T. Dat, "Antiinflammatory effects of fatty acids isolated from Chromolaena odorata," Asian Pacific Journal of Tropical Medicine, vol. 4, no. 10, pp. 760-763, 2011.

[22] P. B.-K. Kouamé, C. Jacques, G. Bedi et al., "Phytochemicals isolated from leaves of chromolaena odorata: Impact on viability and clonogenicity of cancer cell lines," Phytotherapy Research, vol. 27, no. 6, pp. 835-840, 2013. 
[23] M. Onkaramurthy, V. P. Veerapur, B. S. Thippeswamy, T. N. Madhusudana Reddy, H. Rayappa, and S. Badami, "Antidiabetic and anti-cataract effects of Chromolaena odorataLinn. in streptozotocin-induced diabetic rats," Journal of Ethnopharmacology, vol. 145, no. 1, pp. 363-372, 2013.

[24] P. Wafo, R. S. T. Kamdem, Z. Ali et al., "Kaurane-type diterpenoids from Chromoleana odorata, their X-ray diffraction studies and potent $\alpha$-glucosidase inhibition of 16-kauren-19-oic acid," Fitoterapia, vol. 82, no. 4, pp. 642-646, 2011.

[25] M. Madhavan, "Quantitative Estimation of total phenols and antibacterial studies of leaves extracts of Chromolaena odorata (L.) King \& H. E. Robins," International Journal of Herbal Medicine, vol. 3, no. 2, pp. 20-23, 2015.

[26] G. Parameswari and M. Suriyavathana, "In-vitro antioxidant activity chromolaena odorata (L.) king and robinson," International Research Journal of Pharmacy, vol. 3, no. 1, pp. 187-192, 2013.

[27] D. Bhargava, C. Mondal, J. Shivapuri, S. Mondal, and S. Kar, "Antioxidant properties of the leaves of Chromolaena odorata linn," Journal of Institute of Medicine, vol. 35, no. 1, pp. 53-56, 2013.

[28] K. Srinivasa Rao, P. K. Chaudhury, and A. Pradhan, "Evaluation of anti-oxidant activities and total phenolic content of Chromolaena odorata," Food and Chemical Toxicology, vol. 48, no. 2, pp. 729-732, 2010.

[29] J. S. A. Al-Qassabi, A. M. Weli, and M. A. Hossain, "Comparison of total phenols content and antioxidant potential of peel extracts of local and imported lemons samples," Sustainable Chemistry and Pharmacy, vol. 8, pp. 71-75, 2018.

[30] D. A. Putri, A. Ulfi, A. S. Purnomo, and S. Fatmawati, "Antioxidant and antimicrobial activities of Ananas comosus peel extracts," Malaysian Journal of Fundamental and Applied Sciences, vol. 14, no. 2, pp. 307-311, 2018.

[31] S. R. Ayinampudi, R. Domala, R. Merugu, S. Bathula, and M. R. Janaswamy, "New icetexane diterpenes with intestinal $\alpha$-glucosidase inhibitory and free-radical scavenging activity isolated from Premna tomentosa roots," Fitoterapia, vol. 83, no. 1, pp. 88-92, 2012.

[32] T. H. Bang, H. Suhara, K. Doi et al., "Wild mushrooms in Nepal: some potential candidates as antioxidant and ACEinhibition sources," Evidence-Based Complementary and Alternative Medicine, vol. 2014, Article ID 195305, 11 pages, 2014.

[33] W. D. Fitriana, T. Ersam, K. Shimizu, and S. Fatmawati, "Antioxidant activity of Moringa oleifera extracts," Indonesian Journal of Chemistry, vol. 16, no. 3, pp. 297-301, 2016.

[34] N. A. Kristanti, S. N. Aminah, M. Tanjung, and B. Kurniadi, Fitokimia, Airlangga University Press, Surabaya, Indonesia, 1st edition, 2008.

[35] M. D. Hidayati, T. Ersam, K. Shimizu, and S. Fatmawati, "Antioxidant activity of Syzygium polynthum extracts," Indonesian Journal of Chemistry, vol. 17, no. 1, pp. 49-53, 2017.

[36] E. A. Shalaby and S. M. M. Shanab, "Antioxidant compounds, assays of determination and mode of action," African Journal of Pharmacy and Pharmacology, vol. 7, no. 10, pp. 528-539, 2013.

[37] E. R. Sukandar, T. Ersam, S. Fatmawati, P. Siripong, T. Aree, and S. Tip-Pyang, "Cylindroxanthones A-C, three new xanthones and their cytotoxicity from the stem bark of Garcinia cylindrocarpa," Fitoterapia, vol. 108, pp. 62-65, 2016.

[38] T. Ersam, S. Fatmawati, and D. N. Fauzia, "New prenylated stilbenes and antioxidant activities of Cajanus cajan (L.) millsp. (Pigeon pea)," Indonesian Journal of Chemistry, vol. 16, no. 2, pp. 151-155, 2016.
[39] Z. Yin, W. Zhang, F. Feng, Y. Zhang, and W. Kang, " $\alpha$ Glucosidase inhibitors isolated from medicinal plants," Food Science and Human Wellness, vol. 3, no. 3-4, pp. 136-174, 2014.

[40] S. Fatmawati, K. Kurashiki, S. Takeno et al., "The inhibitory effect on aldose reductase by an extract of Ganoderma lucidum," Phytotherapy Research, vol. 23, no. 1, pp. 28-32, 2009.

[41] S. Fatmawati, K. Shimizu, and R. Kondo, "Ganoderic acid Df, a new triterpenoid with aldose reductase inhibitory activity from the fruiting body of Ganoderma lucidum," Fitoterapia, vol. 81, no. 8, pp. 1033-1036, 2010.

[42] S. Fatmawati, T. Ersam, and K. Shimizu, "The inhibitory activity of aldose reductase in vitro by constituents of Garcinia mangostana Linn," Phytomedicine, vol. 22, no. 1, pp. 49-51, 2015.

[43] S. Fatmawati, T. Ersam, H. Yu, C. Zhang, F. Jin, and K. Shimizu, "20(S)-Ginsenoside Rh2 as aldose reductase inhibitor from Panax ginseng," Bioorganic \& Medicinal Chemistry Letters, vol. 24, no. 18, pp. 4407-4409, 2014.

[44] S. Fatmawati, K. Shimizu, and R. Kondo, "Ganoderol B: a potent $\alpha$-glucosidase inhibitor isolated from the fruiting body of Ganoderma lucidum," Phytomedicine, vol. 18, no. 12, pp. 10531055, 2011.

[45] T. Robinson, Kandungan organik tumbuhan tinggi, ITB Publisher, Bandung, Indonesia, 6th edition, 1995. 


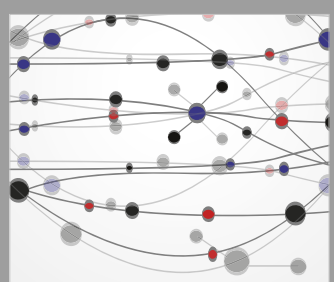

The Scientific World Journal
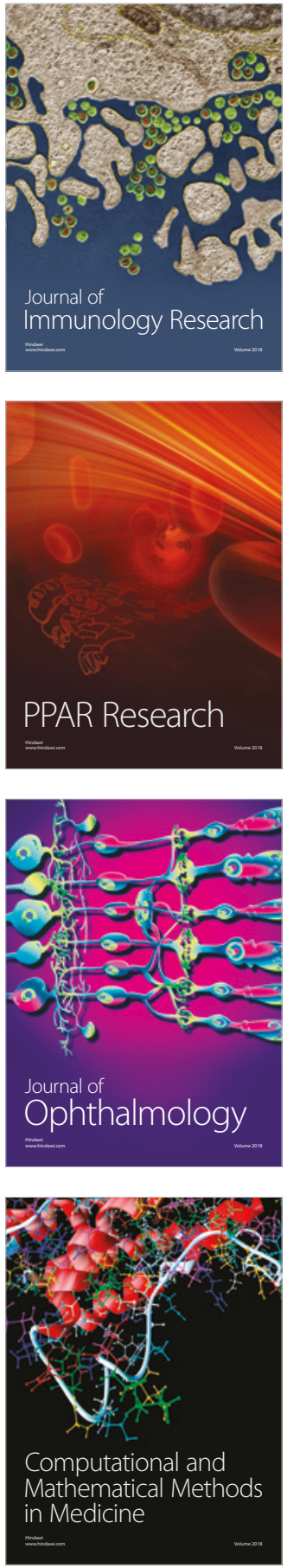

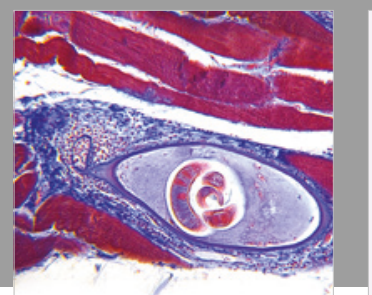

Gastroenterology Research and Practice

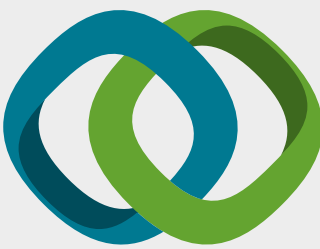

\section{Hindawi}

Submit your manuscripts at

www.hindawi.com
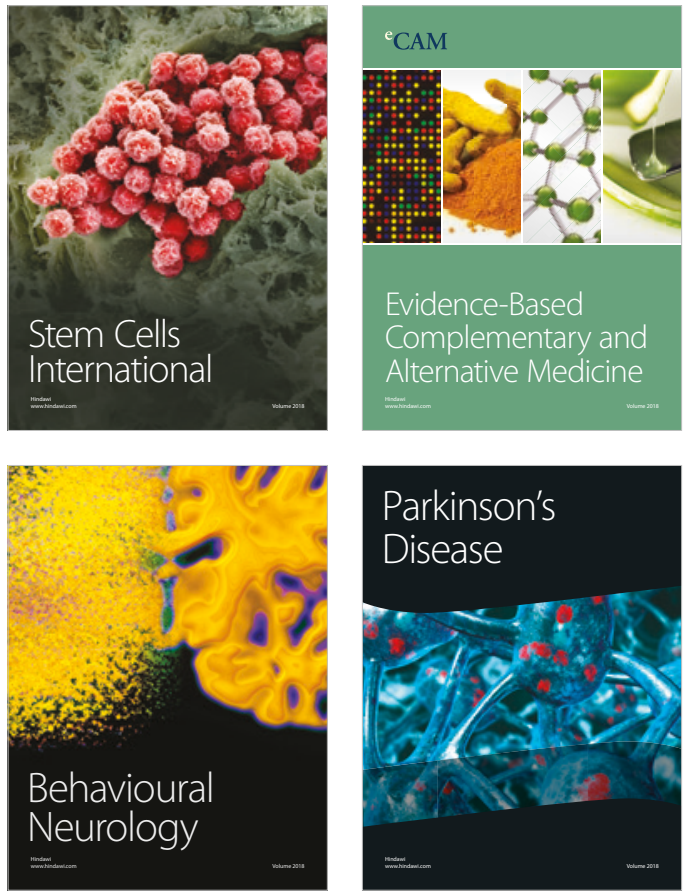

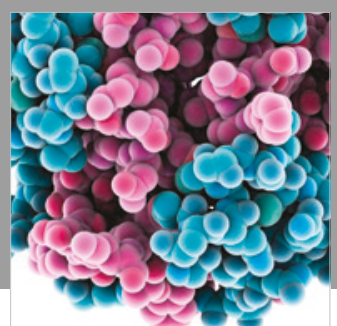

ournal of

Diabetes Research

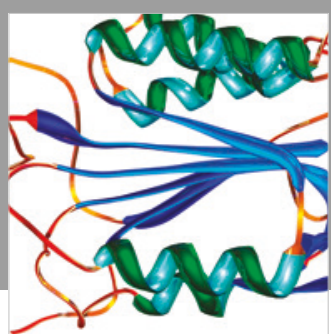

Disease Markers
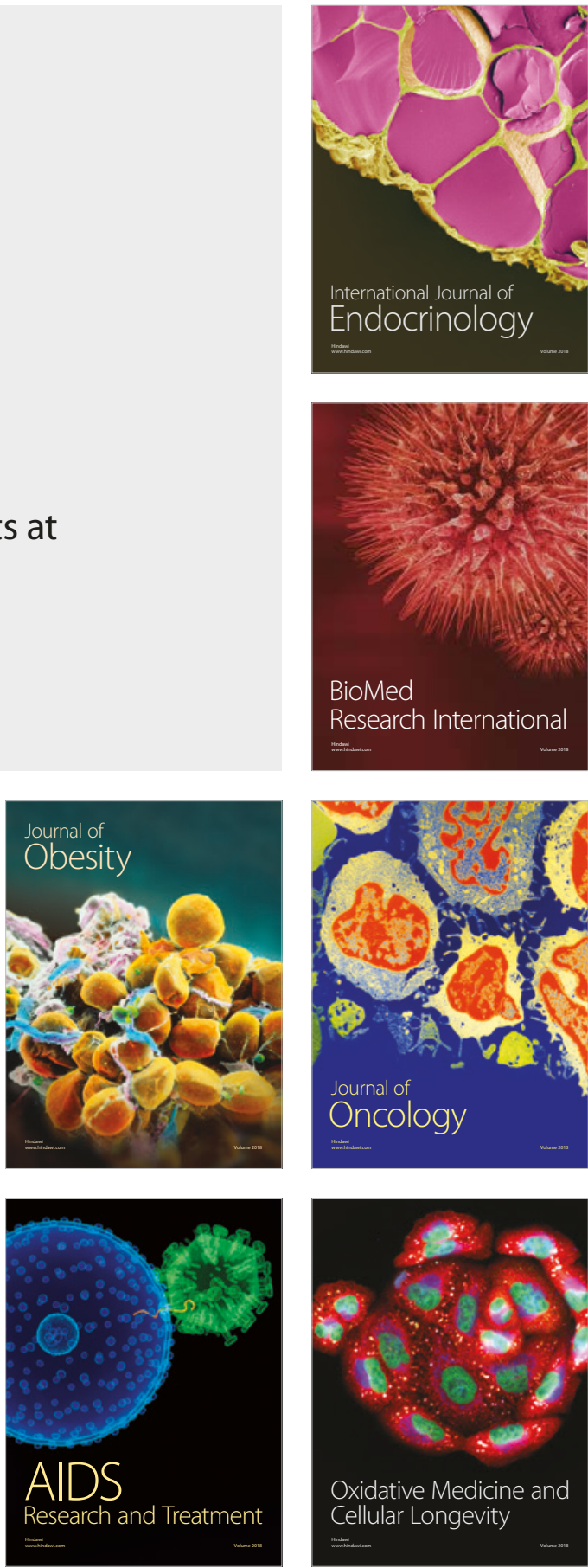